\title{
Mass-balance reconstruction for Glacier No. 354, Tien Shan, from 2003 to 2014
}

\author{
Marlene KRONENBERG, ${ }^{1}$ Martina BARANDUN, ${ }^{1}$ Martin HOELZLE, ${ }^{1}$ Matthias HUSS, ${ }^{1,2}$ \\ Daniel FARINOTTI, ${ }^{3,4}$ Erlan AZISOV, ${ }^{5}$ Ryskul USUBALIEV, ${ }^{5}$ Abror GAFUROV, ${ }^{4}$ \\ Dmitry PETRAKOV, ${ }^{6}$ Andreas KÄ̈̈̈B ${ }^{7}$
}

\author{
${ }^{1}$ Department of Geosciences, University of Fribourg, Fribourg, Switzerland \\ ${ }^{2}$ Laboratory of Hydraulics, Hydrology and Glaciology (VAW), ETH Zürich, Zürich, Switzerland \\ ${ }^{3}$ Swiss Federal Institute for Forest, Snow and Landscape Research (WSL), Birmensdorf, Switzerland \\ ${ }^{4}$ German Research Center for Geoscience (GFZ), Potsdam, Germany \\ ${ }^{5}$ Central Asian Institute of Applied Geosciences (CAIAG), Bishkek, Kyrgyzstan \\ ${ }^{6}$ Faculty of Geography, Lomonosov Moscow State University, Moscow, Russia \\ ${ }^{7}$ Department of Geosciences, University of Oslo, Oslo, Norway \\ Correspondence: Marlene Kronenberg <marlene.kronenberg@unifr.ch>
}

\begin{abstract}
This study presents a reconstruction of the seasonal mass balance of Glacier No. 354, located in the Akshiirak range, Kyrgyzstan, from 2003 to 2014. We use a distributed accumulation and temperature-index melt model driven by daily air temperature and precipitation from a nearby meteorological station. The model is calibrated with in situ measurements of the annual mass balance collected from 2011 to 2014. The snow-cover depletion pattern observed using satellite imagery provides additional information on the dynamics of mass change throughout the melting season. Two digital elevation models derived from high-resolution satellite stereo images acquired in 2003 and 2012 are used to calculate glacier volume change for the corresponding period. The geodetic mass change thus derived is used to validate the modelled cumulative glacier-wide balance. For the period 2003-12 we find a cumulative mass balance of $-0.40 \pm 10 \mathrm{~m} \mathrm{w.e.} \mathrm{a}^{-1}$. This result agrees well with the geodetic balance of $-0.48 \pm 0.07 \mathrm{~m}$ w.e. $\mathrm{a}^{-1}$ over the same period.
\end{abstract}

KEYWORDS: glacier mass balance, glacier volume, remote sensing

\section{INTRODUCTION}

Changes in glacier mass balance directly reflect short- and long-term fluctuations of glaciers in relation to driving meteorological conditions and climate evolution (Oerlemans, 1994; Haeberli and others, 2007). When assessing the future behaviour of a glacier, understanding its response in the past is an asset. In dry regions, such as continental central Asia, water availability is limited but water resources are essential for drinking, agricultural irrigation and energy production (Kaser and others, 2010). In this region, water scarcity and its seasonality could give rise to conflicts (e.g. Allouche, 2007; ECE, 2011). The Tien Shan, with a glacierized area of $\sim 7300 \mathrm{~km}^{2}$ within the former USSR (Khromova and others, 2014), represent a vital water tower for the densely populated lowlands and contribute significantly to runoff during the summer months (Sorg and others, 2012; Kriegel and others, 2013). Hence, understanding the evolution of Tien Shan glaciers is of great interest, to allow greater accuracy in projections of future water availability (e.g. Unger-Shayesteh and others, 2013; Sorg and others, 2014).

Several studies based on remote sensing indicate a large decrease in glacier area (e.g. Aizen and others, 2006; Bolch, 2007; Narama and others, 2010; Ozmonov and others, 2013) and ice volume (e.g. Pieczonka and others, 2013; Wu and others, 2014; Pieczonka and Bolch, 2015) for the Tien Shan. In situ glacier mass-balance measurements are sparse, especially since the mid-1990s when several long-term mass-balance measurements in central Asia were suspended
(WGMS, 2012). Glaciological measurements have been performed on only a few glaciers and over short time periods. In the Kyrgyz Tien Shan, Golubin glacier (Ala Archa region) and Glacier No. 131, Davydov, Gregoriev, Karabatkak, Suek Zapadniy and Sary-Tor glaciers (all in the inner Tien Shan) were investigated (e.g. Dyurgerov and Mikhalenko, 1995). Analysis of the difference between glaciological and geodetic mass balances has been reported for Tuyuksu glacier, northern Tien Shan, Kazakhstan (Hagg and others, 2004) and Ürümqi glacier No. 1, eastern Tien Shan, China (Wang and others, 2014a). Bolch (2015) compared geodetic mass changes of Kyrgyz Ala Archa glaciers with available glaciological measurements.

In the Akshiirak range (Fig. 1), mass-balance observations date back to the 1980s. Glaciological measurements were performed on Sary-Tor glacier for the period 1985-89 (Dyurgerov and others, 1994), and its mass balance was reconstructed from 1930 to 1988 using modelling by Ushnurtsev (1991a). A recent investigation based on remote sensing, modelling and radio-echo sounding determined the ice volume and a slightly decreased rate of area loss for Sary-Tor glacier from 2003 to 2012 compared with 19772003 (Petrakov and others, 2014). Although some massbalance data based on the glaciological method exist for Sary-Tor, it was decided to transfer new monitoring efforts to nearby Glacier No. 354 because of restricted access to SaryTor due to mining activities. Glacier No. 354 was selected for long-term monitoring by a group of researchers from 


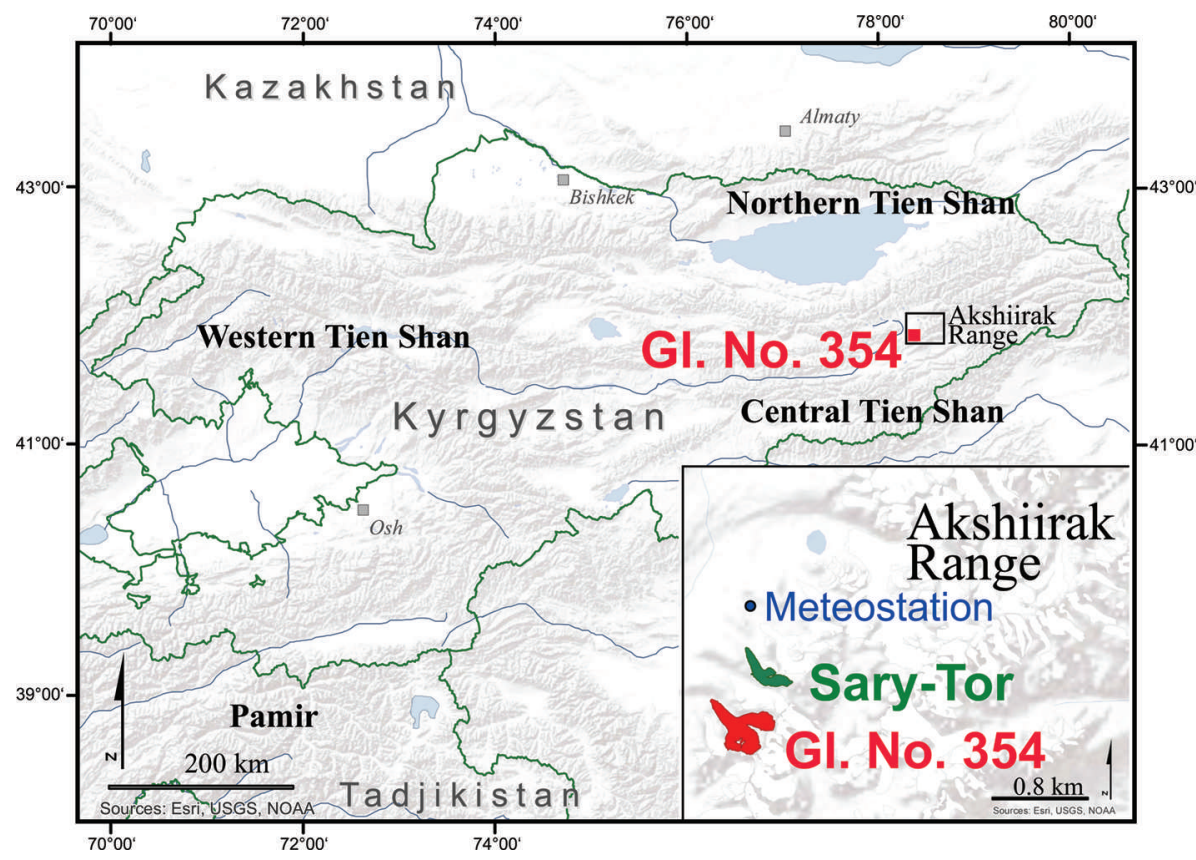

Fig. 1. Location map of Glacier No. 354, Akshiirak range, inner Tien Shan, Kyrgyzstan. Inset: zoom to the Akshiirak range, with the locations of Sary-Tor, Glacier No. 354 and the meteorological station indicated. Source: Environmental Systems Research Institute (ESRI)/US Geological Survey/US National Oceanic and Atmospheric Administration.

Kyrgyzstan, Germany and Switzerland within the projects Central Asian Water (CAWa) and Capacity Building and Twinning for Climate Observing Systems (CATCOS).

The reconstruction of mass-balance time series for glaciers with no or limited in situ measurements is a prerequisite for increasing our understanding of the glacier response to climate forcing. Today, models are common tools for reconstructing glacier-wide surface mass balance. A prevalent approach is the use of degree-day models, which are based on empirical relations (e.g. Braithwaite and Olesen, 1989; Hock, 2003; Pellicciotti and others, 2005; Huss and others, 2008). Degree-day models are well suited for mass-balance reconstruction if only limited input data exist. As they are based on the high correlation between certain components of the energy balance (longwave incoming radiation and sensible heat flux) with air temperature (Ohmura, 2001) they perform well, especially for periods for which calibration data are available.

The main objective of this study is to determine the seasonal glacier-wide mass balance of Glacier No. 354 from 2003 to 2014 with a distributed mass-balance model. The model is calibrated with in situ measurements of both annual mass balance collected from 2011 to 2014 and winter accumulation measurements in 2014, and is driven with meteorological data from a nearby automatic weather station (AWS). Using observations of the transient snowline obtained from remotely sensed images, the seasonal massbalance values given by the model are evaluated. In addition, we produce a set of two digital elevation models (DEMs) from QuickBird and GeoEye satellite stereo images acquired in 2003 and 2012 to estimate the glacier volume change for the corresponding period, and to subsequently validate the modelled cumulative mass balance. By combining these different approaches we provide evidence of mass loss for a glacier within a mountain region for which very little information on mass-balance evolution was available for the last decade.

\section{STUDY SITE AND FIELD DATA}

Glacier No. $354\left(41.80^{\circ} \mathrm{N}, 78.15^{\circ} \mathrm{E}\right)$ is a non-surging valleytype glacier located in the Akshiirak range, inner Tien Shan (Fig. 1). According to data from the nearby Tien Shan Kumtor AWS (Fig. 1), mean annual precipitation was $360 \mathrm{~mm}$ in 1997-2014, of which 75\% was recorded during summer (May-September; Fig. 2). The polythermal glacier, with a compound basin of three tributary accumulation zones, has a surface area of $6.44 \mathrm{~km}^{2}$ (in 2012) and an ice volume of $\sim 272 \times 10^{6} \mathrm{~m}^{3}$ according to ground-penetrating radar measurements in 2010 (Hagg and others, 2013). The glacier covers an altitude range of 3750-4680 m a.s.l.

Since 2010, in situ mass balance has been determined annually in late summer on Glacier No. 354. Ablation is measured using wooden and plastic stakes which are drilled into the ice with a Heucke steam drill. In the accumulation area, snow pits were dug to measure snow depth and density. The observation network consists of 9-12 ablation

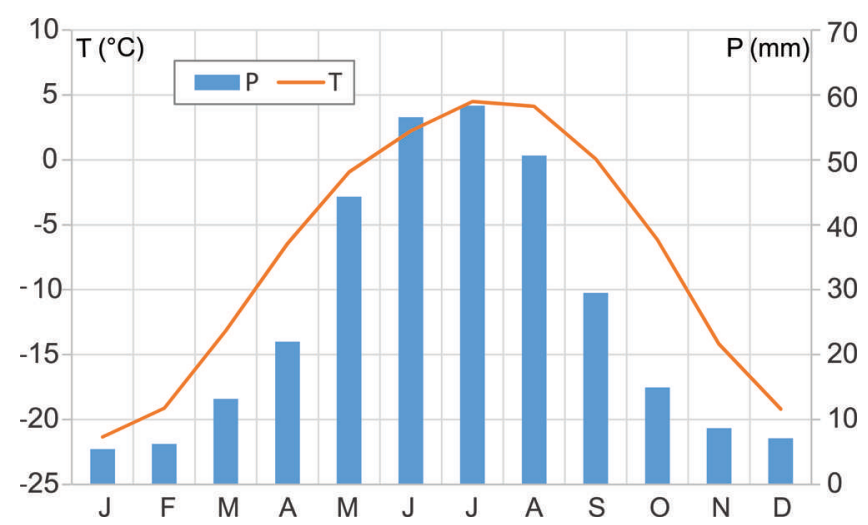

Fig. 2. 1997-2014 monthly precipitation sums (blue) and air temperature averages (orange) for the Tien Shan Kumtor AWS (3660 m a.s.l.). 

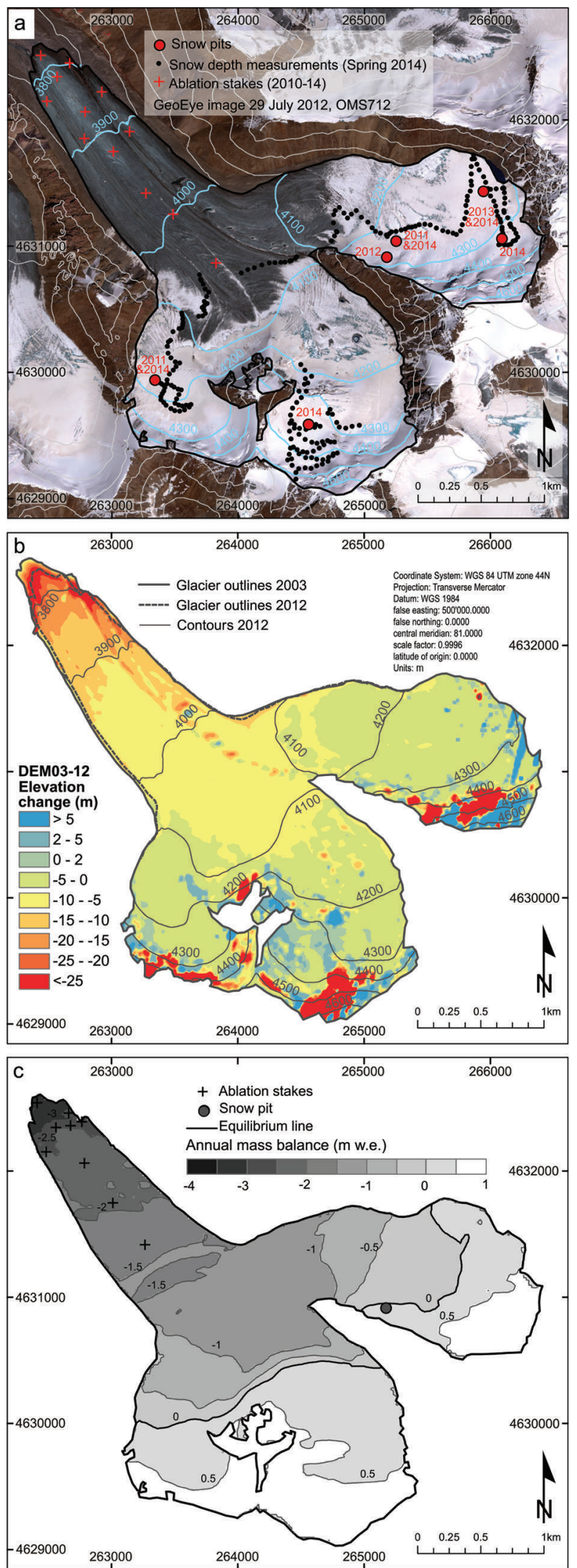

Fig. 3. (a) Observation network on Glacier No. 354 installed in 2010. Annual mass balance was measured annually between 17 and 29 August for 2010/11 to 2013/14. Crosses show the location of ablation stakes, and circles show the snow-pit locations. In May 2014, snow depth measurements were performed (dots). (b) Distribution of elevation change between the DEMs from 2003 and 2012. (c) Calculated mass-balance distribution for the hydrological year 2011/12 based on in situ stake and snow-pit data (indicated by symbols).
Table 1. Input data for DEM generation (QuickBird and GeoEye) and for glacier and snowline mapping (Landsat)

Date
$\mathrm{dd} / \mathrm{mm} / \mathrm{yy}$

$\begin{array}{ll}\text { QuickBird } & 01 / 09 / 03 \\ \text { GeoEye } & 29 / 07 / 12\end{array}$

Landsat 5

12/08/06, 13/09/06, 11/05/07, 30/07/07, 16/09/07 26/07/09, 27/08/09, 11/09/11

Landsat $7 \quad 11 / 06 / 04,14 / 08 / 04,01 / 10 / 04,01 / 08 / 05,20 / 06 / 07$, 08/09/07, 24/09/07, 11/07/09, 17/07/11, 26/09/11, 03/07/12, 28/09/12, 29/07/13, 01/10/013, 09/07/14 25/07/14, 10/08/14 18/09/14

Landsat 8 06/08/13, 15/08/13, 07/09/13, 23/09/13, 01/07/14 $10 / 09 / 14$

stakes and one or two snow pits (Fig. 3a). Further information on stake data can be obtained from the World Glacier Monitoring Service (WGMS, 2014). In May 2014 we also measured winter snow accumulation distribution with five pits and $\sim 200$ manual snow probings (Fig. 3a). Measured ice ablation is converted into water equivalent assuming an ice density of $900 \mathrm{~kg} \mathrm{~m}^{-3}$.

We use precipitation and temperature data recorded between 1 October 2003 and 30 September 2014 at the Tien Shan Kumtor AWS $\left(41.92^{\circ} \mathrm{N}, 78.23^{\circ} \mathrm{E}\right), \sim 14 \mathrm{~km}$ from Glacier No. 354, located at 3660 m a.s.l. (Fig. 1). The AWS is located next to the mine camp and began operating on 19 August 1996, replacing the old Tien Shan station. Hourly data are calculated as a mean from measurements which have been acquired every $5 \mathrm{~s}$. Sensors are calibrated annually. Here we use daily precipitation sums and daily mean temperatures which are derived from the official hourly values. Unfortunately, no information on data quality and filtering is available. Monthly temperature lapse rates calculated from six stations (Aizen and others, 1995) are applied to extrapolate measured temperature to the mean elevation of Glacier No. 354.

We use two stereo pairs of the QuickBird and GeoEye satellites from 1 September 2003 and 29 July 2012 to create two DEMs (see below) and corresponding glacier outlines. Orthorectified and georeferenced Landsat Thematic Mapper (TM)/Enhanced TM Plus (ETM+) and Operational Land Imager (OLI)/Thermal Infrared Sensor (TIRS) images of appropriate quality are chosen to manually map the glacier boundary for each year from 2003 to 2014. No suitable images were found for 2008 and 2010. Uncertainties related to manually digitized glacier outlines on remote imagery are expected to be within $\pm 5 \%$ (Paul and others, 2013), i.e. $\pm 0.35 \mathrm{~km}^{2}$ for Glacier No. 354. Additionally, all available Landsat TM/ETM+ and OLI/TIRS scenes with low cloud coverage during the study period between May and September (i.e. during the ablation season, 32 scenes in total), are used to gain information on snow depletion patterns (Table 1 ).

\section{METHODS}

\section{Mass-balance model}

The idea behind the method used to determine the glacierwide surface mass balance for Glacier No. 354 is to constrain a distributed model with seasonal field observations. 
Required input data are (1) point mass-balance measurements at a limited number of locations over an arbitrary period of $\sim 1$ year, (2) snow probings in spring, (3) a DEM and glacier outlines and (4) daily air temperature and precipitation data. The model provides daily mass-balance time series for every gridcell of the glacier and thus allows (1) an extrapolation of measured point mass balance based on an algorithm that includes the main processes governing mass-balance distribution, (2) the determination of glacierwide mass balance over, for example, the hydrological year and (3) the separation of mass-balance components (accumulation/ablation).

Here we use a distributed accumulation and temperatureindex melt model (Hock, 1999; Huss and others, 2008). Degree-day factors are varied as a function of potential direct solar radiation, in order to account for the effects of slope, aspect and shading. Daily surface melt rates, $M=M(x, y, t)$, at day $t$ and for gridcell $(x, y)$ of the DEM are computed by

$$
M= \begin{cases}\left(f_{M}+r_{\text {snow } / \text { ice }} I_{\text {pot }}\right) T & : \quad T>0^{\circ} \mathrm{C} \\ 0 & : \quad T \leq 0^{\circ} \mathrm{C}\end{cases}
$$

where $f_{\mathrm{M}}$ denotes a melt factor, $r_{\text {snow/ice }}$ are radiation factors for ice and snow surfaces and $I_{\text {pot }}=I_{\text {pot }}(x, y, t)$ is the potential solar radiation under clear-sky conditions (calculated after Hock, 1999). Air temperature, $T=T(x, y, t)$, is extrapolated from mean glacier elevation to every gridcell, using a constant lapse rate, $\mathrm{d} T / \mathrm{dz}=-4.7^{\circ} \mathrm{C} \mathrm{km}^{-1}$ (Aizen and others, 1995). Snow accumulation, $C$, is calculated based on the measured precipitation, $P_{\mathrm{WS}}(t)$, at the weather station occurring at temperatures smaller than a threshold temperature, $T_{\text {thr }}=1.5^{\circ} \mathrm{C}$, by

$$
C(x, y, t)=P_{\mathrm{WS}}(t) \cdot C_{\text {prec }} \cdot D_{\text {snow }}(x, y) \text {. }
$$

A correction factor, $C_{\text {prec}}$, allows the adjustment of precipitation sums. The spatial variation in accumulation over the glacier is taken into account using a dimensionless spatial snow distribution multiplier, $D_{\text {snow }}(x, y)$ (Farinotti and others, 2010). $D_{\text {snow }}(x, y)$ is derived by spatially interpolating the snow water equivalent, measured in the field over the entire glacier using an inverse-distance scheme, and the interpolated field is normalized to an average of 1 . Thus, processes of preferential deposition of snow, as well as snowdrift, are included in the model via field measurements integrating the winter accumulation season. We assume that the spatial snow distribution observed in May 2014 is valid for all years, but assess the impact of this assumption with a sensitivity experiment.

For the years with in situ measurements (2011-14) the model is calibrated for each year individually in a semiautomatic procedure. $C_{\text {prec }}($ Eqn (2)) is constrained based on the direct winter accumulation measurements in May 2014, and is assumed to remain constant over time. Initially, $C_{\text {prec }}$ was set to 1.3, assuming that precipitation at the elevation of the glacier was somewhat higher than at the AWS. $C_{\text {prec }}$ was then automatically varied until the root-mean-square error (RMSE) between modelled and observed winter accumulation measurements was minimal. The melt parameters, $f_{M}$, $r_{\text {snow }}$ and $r_{\text {ice }}(\operatorname{Eqn}(1))$, are set to initial values based on the literature and then automatically adjusted with a constant ratio between them, so that the RMSE between modelled and observed point annual balances is minimized. The remaining RMSE were in the range $0.29-0.38 \mathrm{mw}^{\mathrm{e}} \mathrm{e} \mathrm{a}^{-1}$. The average values from the consolidated parameter set
Table 2. Averaged values of calibrated model parameters (used for 2003/04-2009/10) and ranges of calibrated model parameters $(2010 / 11-2013 / 14)$ and units

\begin{tabular}{lccc}
\hline Parameter & Value & Range & Unit \\
\hline$f_{\mathrm{M}}$ & 1.41 & $1.36-1.47$ & $10^{-3} \mathrm{mw}$ w.e. $\mathrm{d}^{-1}{ }^{\circ} \mathrm{C}^{-1}$ \\
$r_{\text {snow }}$ & 1.13 & $1.08-1.18$ & $10^{-5} \mathrm{mw.e.}(\mathrm{W} \mathrm{m})^{-2} \mathrm{~d}^{-1}{ }^{\circ} \mathrm{C}^{-1}$ \\
$r_{\text {ice }}$ & 2.26 & $2.18-2.35$ & $10^{-5} \mathrm{mw}$.e. $\left(\mathrm{W} \mathrm{m}^{-2}\right)^{-1} \mathrm{~d}^{-1}{ }^{\circ} \mathrm{C}^{-1}$ \\
$\mathrm{~d} T / \mathrm{d} z$ & -4.7 & const. & ${ }^{\circ} \mathrm{C} \mathrm{km}^{-1}$ \\
$C_{\text {prec }}$ & 1.63 & const. & - \\
\hline
\end{tabular}

determined over 2011-14 are then used to drive the model for 2003 to 2010 using the meteorological input from the AWS (Table 2).

The presented mass balances are given in a fixed-date system for the hydrological year (1 October-30 September; Cogley and others, 2011). Mass-balance values are calculated over a changing glacier surface (conventional mass balance; Elsberg and others, 2001) to allow direct comparison between glaciological and geodetic methods. We used annually updated DEMs and glacier masks for the modelling between 2004 and 2011, and constant glacier geometry after 2012. Approximated annual DEMs were obtained by linearly interpolating observed surface elevation changes (Huss and others, 2008) between the QuickBird and GeoEye DEMs of 2003 and 2012 (see below), and glacier area was adapted based on Landsat imagery.

\section{Snow-covered area fraction}

We used transient snowline observations derived from remotely sensed images from 2004 to 2014 to verify the plausibility of the modelled seasonal mass-balance values. The transient snowline is regarded as a proxy for subseasonal mass balance (Pelto, 2011; Huss and others, 2013). For each year, between one and six georeferenced Landsat TM/ETM+ and OLI/TIRS images with good visibility were identified during the period of depletion of the winter snow cover (Table 1). We manually digitized the snowline by visual separation of bare ice and snow (Hulth and others, 2013; Huss and others, 2013) on the false-colour composites of the satellite images. The snow-covered area fraction (SCAF), i.e. the fraction of the glacier area covered by seasonal snow, is calculated for each observation date. This quantity is then compared with the modelled SCAF at the corresponding dates. The mass-balance model provides the surface type (snow or ice) per pixel at daily resolution, which allows direct extraction of the SCAF.

\section{DEM generation and comparison}

We created DEMs with a spatial resolution of $4 \mathrm{~m}$ from the two stereo pairs of QuickBird (1 September 2003) and GeoEye (29 July 2012) high-resolution satellite imagery, using standard procedures and the software PCI Geomatica. The two stereo pairs were connected using common tie points before DEM extraction, and no horizontal shift between the two DEMs was found (Nuth and Kääb, 2011). The mean elevation difference for non-glacierized areas was $0.5 \mathrm{~m}$, indicating a higher mean elevation for the year 2003 than for 2012. This offset was corrected to obtain a zero mean elevation difference outside the glaciers. For this vertical co-registration, only flat terrain sections were selected and areas with parallax-matching problems were 
Table 3. Uncertainty analysis of glaciological and geodetic mass balances. $\sigma_{\text {glac }}$ is the average uncertainty in glaciological mass balance for 2011-14, and $\sigma_{\text {rec }}$ is the average uncertainty for the reconstructed period 2003-10. $\sigma_{\Delta \mathrm{h}}$ is the total uncertainty of individual elevation differences, $\sigma_{\text {ground }}$ is the uncertainty in the vertical stable ground offset, $\sigma_{\rho}$ is the uncertainty resulting from the density assumption and $\sigma_{\text {geod }}$ is the total uncertainty of the geodetic mass balance

\begin{tabular}{lcc}
\hline Symbol & Uncertainty in & Value \\
\hline$\sigma_{\text {glac }}$ & Glaciological balances 2011-14 & $\pm 0.24 \mathrm{~m} \mathrm{w.e.}^{-1}$ \\
$\sigma_{\text {rec }}$ & Reconstructed balances 2003-10 & $\pm 0.33 \mathrm{~m} \mathrm{w.e.} \mathrm{a}^{-1}$ \\
$\sigma_{\Delta h}$ & Individual elevation differences & $\pm 0.34 \mathrm{~m} \mathrm{w.e.} \mathrm{a}^{-1}$ \\
$\sigma_{\text {ground }}$ & Stable ground offset correction & $\pm 0.14 \mathrm{~m} \mathrm{w.e.} \mathrm{a}^{-1}$ \\
$\sigma_{\rho}$ & Density assumption & $\pm 0.03 \mathrm{~m} \mathrm{w.e.} \mathrm{a}^{-1}$ \\
$\sigma_{\text {geod }}$ & Geodetic balance 2003-12 & $\pm 0.07 \mathrm{~m} \mathrm{w.e.}^{-1}$ \\
\hline
\end{tabular}

avoided. As the 2003 image has a quite oblique view angle $\left(\sim 30^{\circ}\right)$, the two images of the stereo pair are strongly distorted relative to each other in the steep upper parts of the glacier. This results in problems for parallax matching and thus obvious DEM errors (Fig. 3b). We therefore used robust statistics to estimate the total volume change (Höhle and Höhle, 2009). For each $100 \mathrm{~m}$ elevation bin, the median elevation difference was computed, and these medians were multiplied by the area of each bin and then integrated over the entire glacier to obtain the total volume change, $\Delta V$.

To compare the glaciological and the geodetic mass balance, the volume change was corrected to the start and end dates of the hydrological year (1 October 2003 to 30 September 2012) with modelled information on massbalance evolution for the periods between image-acquisition dates and the start/end of the hydrological year. The difference in volume change calculated in this way was converted into a mass change, $B_{\text {geod, }}$ using a density of $\rho_{\Delta V}=850 \pm 60 \mathrm{~kg} \mathrm{~m}^{-3}$ (Huss, 2013):

$$
B_{\text {geod }}=\frac{\Delta V \cdot \rho_{\Delta V}}{\bar{A} \cdot \Delta t}
$$

where $\bar{A}$ is the average glacier area from 2003 and 2012 over the time interval $\Delta t=9$ years.

\section{Uncertainty analysis}

The uncertainty in the calculated glaciological glacier-wide mass balance for 2011-14, $\sigma_{\text {glac, }}$ and in the reconstructed glacier-wide mass balance, $\sigma_{\text {rec }}$, for $2003-10$ is the result of a combination of uncertainties that are related to (1) the in situ measurements, $\sigma_{\mathrm{abl}}$ and $\sigma_{\mathrm{acc}}$ for ablation and accumulation measurements, respectively, (2) the model uncertainty related to the chosen parameters, $\sigma_{\bmod },(3)$ the uncertainties of assumptions on the snow distribution, $\sigma_{\text {sd }}$, and (4) a missing parameter optimization for the period without available measurements (2003-10), $\sigma_{\text {opt }}$.

The uncertainties in point measurements of ablation and accumulation are adopted from Thibert and others (2008). They performed repeated tests for ablation measurements on ice and found an uncertainty of $15 \mathrm{~cm}$. With an ice density of $900 \mathrm{~kg} \mathrm{~m}^{-3}$ and the number of ablation measurements per year, $N$, the total uncertainty in the annual point ablation measurements is $\sigma_{\mathrm{abl}}=0.14 / \sqrt{\mathrm{N}} \mathrm{m}$ w.e. $\mathrm{a}^{-1}$. The uncertainty in the accumulation, $\sigma_{\mathrm{acc}}$, (excluding stratigraphic errors) consists of the uncertainty in the density measurement and the uncertainty in the observed snow depth. The annual uncertainty resulting from these components is $\sigma_{\text {acc }}=0.13$ m w.e. $\mathrm{a}^{-1}$.

The uncertainty $\sigma_{\text {mod }}$ is mainly affected by the choice of model parameters. This uncertainty was assessed by rerunning the model for the period 2003-14 with a set of parameters that differ from the calibrated values. In the altered parameter set, the values for $c_{\text {prec }}$ were varied by $\pm 25 \%$. The temperature lapse rate was varied between different literature values, i.e. between $3.0^{\circ} \mathrm{C} \mathrm{km}^{-1}$ (Aizen and others, 1995) and $5.8^{\circ} \mathrm{C} \mathrm{km}^{-1}$ (Aizen and Aizen, 1997). The standard deviation of the annual differences between the results obtained from the calibrated and altered parameter sets is interpreted as an estimate for $\sigma_{\text {mod }}$. In our experiment, we found $\sigma_{\text {mod }}=0.19 \mathrm{mw}$.e. $\mathrm{a}^{-1}$.

The snow distribution used in the modelling is based on measurements from one field survey only. No information is available on the temporal evolution of the snow depth pattern. To estimate the impact of this effect we reran the model with the assumption of a uniform snow distribution with $D_{\text {snow }}(x, y)=1=$ constant. The standard deviation of the annual differences between the results obtained including the snow distribution pattern from 2014 and using the uniform snow distribution is interpreted as $\sigma_{\text {sd }}$. We found $\sigma_{\mathrm{sd}}=0.12 \mathrm{~m}$ w.e. $\mathrm{a}^{-1}$.

To quantify model uncertainties due to missing parameter optimization from 2003 to 2010, $\sigma_{\text {opt, }}$ we compared model runs with and without calibrating them to in situ measurements for the years 2011-14 with available point data. The standard deviation of $\sigma_{\text {opt }}=0.17 \mathrm{~m}$ w.e. $\mathrm{a}^{-1}$ is interpreted as the uncertainty related to non-optimized modelled massbalance results from 2003 to 2010. We also analysed the model-based temporal homogenization using the same parameter set as for the quantification of $\sigma_{\text {mod }}$. Differences in mass balances at the end of the hydrological year between model runs with the calibrated and the altered parameter sets are not significant, so we assume that this uncertainty is negligible. The final estimates for the overall uncertainties, $\sigma_{\text {glac }}$ for 2011-14 and $\sigma_{\text {rec }}$ for 2003-10, were then obtained by combining all components described above using the rules of Gaussian error propagation (Table 3).

The uncertainty in the annual geodetic mass change, $\sigma_{\text {geod, }}$ was estimated as the root-sum-square (RSS) of (1) the uncertainty of individual elevation differences, (2) the uncertainty of the vertical stable ground offset of $-0.5 \mathrm{~m}$ and (3) the uncertainty in the density assumption. The individual components were estimated as follows. (1) The uncertainty of individual elevation differences is estimated as the normalized median absolute deviation (Höhle and Höhle, 2009). This is a rather pessimistic estimate as it is based on both elevation errors and real spatial variations of elevation change. (2) The elevation offset from stable ground around the glacier of $-0.5 \mathrm{~m}$ has a standard deviation of $1.5 \mathrm{~m}$ that was added to the error budget. (3) The uncertainty of the density assumption, $\pm 60 \mathrm{~kg} \mathrm{~m}^{-3}$, was also added to the error budget. The RSS of the above three error components was the estimated accuracy of individual water-equivalent elevation changes. To arrive at the accuracy for the mean elevation change and the total mass change, the accuracy of individual elevation changes has to be divided by the square root of the effective number of independent measurements, $N_{\text {eff }}$. As neighbouring 
photogrammetric measurements are highly correlated, the distance between independent measurements is far larger than the DEM grid size. Here, we assume a distance between independent measurements of $500 \mathrm{~m}$ (Gardelle and others, 2013), which results in $N_{\text {eff }} \sim 25$.

\section{RESULTS}

By subtracting the DEMs of 2003 and 2012, a total volume change of $-28 \times 10^{6} \mathrm{~m}^{3}$, corresponding to an annual geodetic mass balance of $-0.48 \pm 0.07 \mathrm{mw}^{\mathrm{e}} \mathrm{e} . \mathrm{a}^{-1}$, was found. The glacier experienced elevation losses of up to $25 \mathrm{~m}$ over the glacier tongue, with gradually decreasing values towards the accumulation area (Fig. 3b). We detect elevation changes in the range of $-5 \mathrm{~m}$ in the region of the modelled ELA (Table 4), providing evidence that the glacier has not been in steady state over the last decade. The observed volume change corresponds to a reduction in total glacier volume (Hagg and others, 2013) of 10\% between 2003 and 2012, or slightly more than $1 \% \mathrm{a}^{-1}$.

Between 2011 and 2014, annual mass balances based on the glaciological method are clearly negative (Table 4). For this period, the strongest mass loss was found for 2013/14 $\left(-0.64\right.$ m w.e. $\left.\mathrm{a}^{-1}\right)$. The modelled annual melt and accumulation is shown in Figure 4 for every mass-balance year. The year 2013/14 was characterized by rather small accumulation, although melting was close to average. The massbalance distribution for 2011/12 is shown in Figure 3c. Glacier No. 354 experienced slightly above average snow accumulation and ablation in 2011/12 (Fig. 4), resulting in a mass balance of $-0.46 \mathrm{~m}$ w.e. $\mathrm{a}^{-1}$. The ELA for the same hydrological year was found to be at $4205 \mathrm{~m}$ a.s.I., which is close to the mean over the study period (Table 4).

The reconstructed annual mass balances from 2003-10 are negative except for 2008/09 (Table 4). In this year, snow and ice melt were strongly reduced, due to lower air temperatures and a snow cover protecting the ice surface from melting for much of the ablation season (not shown). The most negative mass balance is found for the year 2005/ $06\left(-0.82 \mathrm{~m}\right.$ w.e. $\left.\mathrm{a}^{-1}\right)$, characterized by the highest ablation during the study period (Fig. 4).
Table 4. Modelled seasonal mass balance of Glacier No. 354 from 2003/04 to 2013/14 with $B_{\mathrm{w}}$ the winter balance between 1 October and 31 May, and $B_{\mathrm{a}}$ the mass balance over the hydrological year. For the years 2010/11-2013/14 the mass balances are directly based on the in situ measurements. The model was used to extrapolate these measurements to the entire glacier surface. For the other years (2003/04-2009/10) an averaged parameter set was used and the mass-balance values are based on the model. Stated confidence intervals refer to $\sigma_{\text {glac }}$ and $\sigma_{\text {rec }}$. $B_{\text {geod }}$ is the mass change determined with the geodetic method for 2003-12

\begin{tabular}{lcccc}
\hline Year & $\begin{array}{c}\text { Area } \\
\mathrm{km}^{2}\end{array}$ & $\begin{array}{c}\text { ELA } \\
\mathrm{m} \text { a.s.l. }\end{array}$ & $\begin{array}{c}B_{\mathrm{w}} \\
\mathrm{mw} \text {.e. }\end{array}$ & $\begin{array}{c}B_{\mathrm{a}} \\
\mathrm{mw} . \mathrm{e} .\end{array}$ \\
\hline $2003 / 04$ & 6.53 & 4175 & $0.38 \pm 0.18$ & $-0.31 \pm 0.34$ \\
$2004 / 05$ & 6.51 & 4185 & $0.31 \pm 0.17$ & $-0.35 \pm 0.32$ \\
$2005 / 06$ & 6.51 & 4295 & $0.23 \pm 0.15$ & $-0.82 \pm 0.35$ \\
$2006 / 07$ & 6.49 & 4185 & $0.22 \pm 0.16$ & $-0.37 \pm 0.33$ \\
$2007 / 08$ & 6.49 & 4245 & $0.19 \pm 0.15$ & $-0.48 \pm 0.31$ \\
$2008 / 09$ & 6.48 & 4115 & $0.30 \pm 0.16$ & $+0.21 \pm 0.29$ \\
$2009 / 10$ & 6.47 & 4235 & $0.26 \pm 0.16$ & $-0.60 \pm 0.35$ \\
$2010 / 11$ & 6.47 & 4195 & $0.30 \pm 0.18$ & $-0.41 \pm 0.24$ \\
$2011 / 12$ & 6.44 & 4205 & $0.34 \pm 0.17$ & $-0.46 \pm 0.26$ \\
$2012 / 13$ & 6.42 & 4225 & $0.29 \pm 0.17$ & $-0.55 \pm 0.25$ \\
$2013 / 14$ & 6.41 & 4275 & $0.12 \pm 0.15$ & $-0.64 \pm 0.22$ \\
$2003-10$ & & 4205 & $0.27 \pm 0.06$ & $-0.39 \pm 0.12$ \\
$2003-14$ & & 4212 & $0.27 \pm 0.05$ & $-0.43 \pm 0.09$ \\
$2003-12$ & & 4204 & $0.28 \pm 0.06$ & $-0.40 \pm 0.10$ \\
$B_{\text {geod }}(2003-12)$ & & & & $-0.48 \pm 0.07$ \\
\hline
\end{tabular}

Over the period 2003-14, the mass balance of Glacier No. 354 only showed small interannual variations (Fig. 5). The calculated 2003-12 cumulative mass balance agrees well with the independent geodetic mass change (Fig. 5), although the mass balance inferred from the glaciological method and modelling is somewhat less negative than that from the geodetic method. The difference $\left(0.08 \mathrm{mw}\right.$.e. $\left.\mathrm{a}^{-1}\right)$ is, however, not significant and is within the error bars of both methods. Hence, we do not correct our reconstructed annual mass-balance series to the mass change found by DEM differencing.

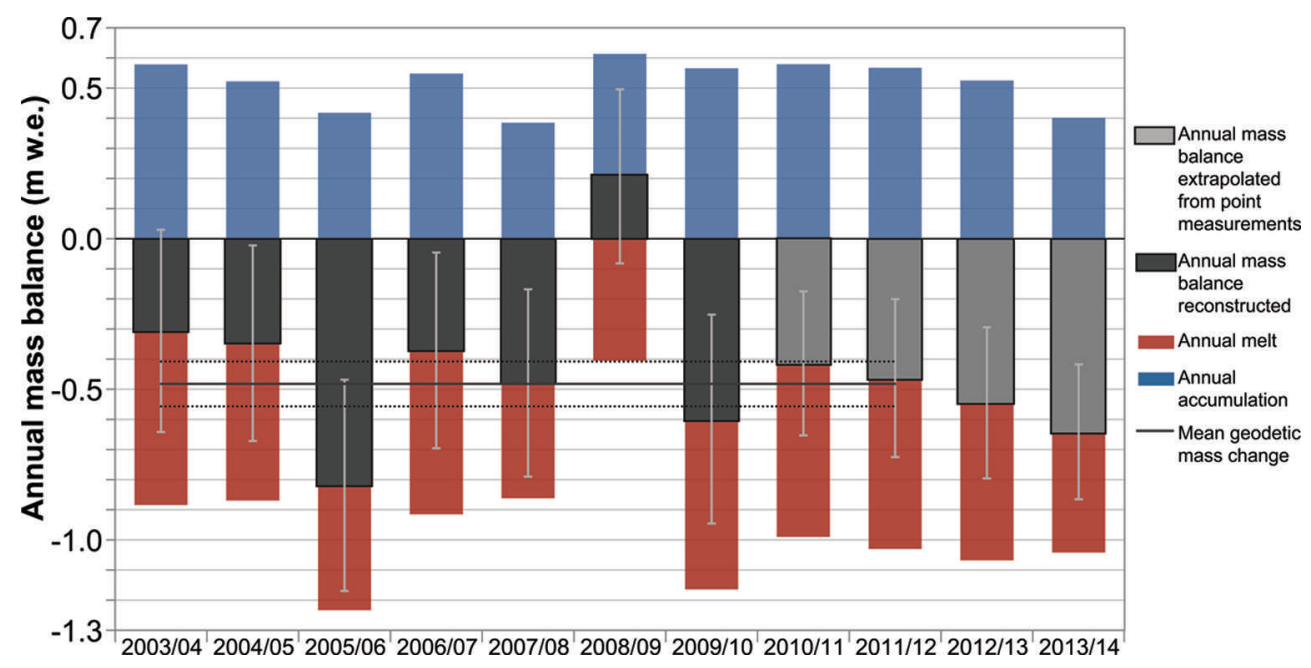

Fig. 4. Reconstructed annual mass balance (dark grey bars) with calculated total annual melt (red) and accumulation (blue) for 2003-10. Mass balances from 2011 to 2014 (light grey bars) are directly based on the in situ measurements. The model was used to extrapolate these point measurements to the entire glacier surface and to the hydrological year. The error bars indicate combined uncertainties, $\sigma_{\text {glac }}$ and $\sigma_{\text {rec }}$. The black line refers to the mean annual geodetic mass balance with its uncertainty (dashed lines). 


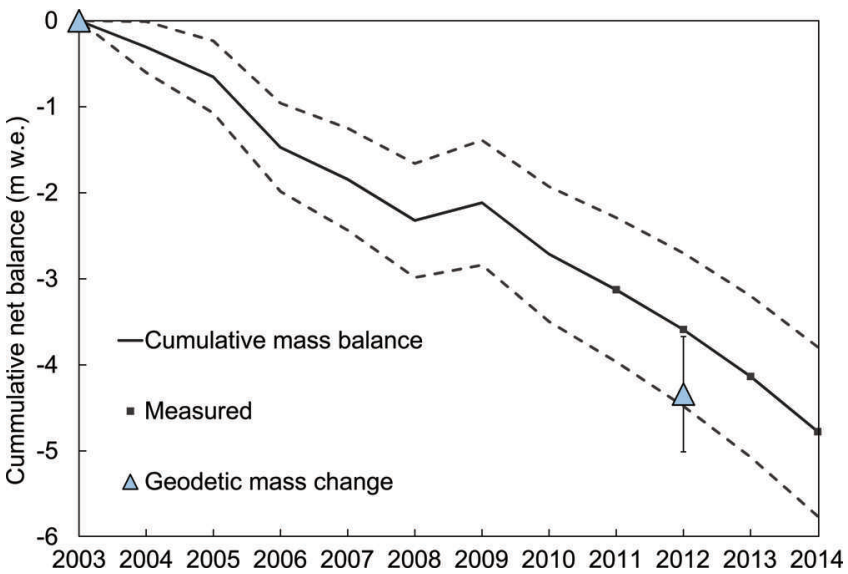

Fig. 5. Cumulative mass balance of Glacier No. 354 (solid curve) and corresponding uncertainties (dashed curves). Mass balances for 2011-14 are measured, and they are modelled for 2003-10. Triangles show the geodetic mass balance, and related uncertainties are indicated.

\section{DISCUSSION}

\section{Validation using snowline observations}

The accuracy of the reconstructed mass-balance series over the period 2003-12 was assessed by comparing cumulative results against the independent geodetic ice volume changes (Fig. 5). We also utilized multiple snowline observations from Landsat imagery throughout the ablation season to validate the model-based seasonal to annual balance and its calculated distribution. For each Landsat image, observed snow-covered area fractions are compared with the model results for the corresponding dates. We find satisfying agreement, with a RMSE of $\pm 14.3 \%$, including all 32 observation dates from 2003-14. Twelve of the 14 fresh snowfall events observed on the Landsat images are correctly identified by the model (not shown). Figure 6 illustrates a comparison between the modelled and observed SCAF over the 2004, 2007 and 2013 ablation seasons.

\section{Mass-balance variations in the Tien Shan}

The average mass balance of $-0.43 \mathrm{~m}$ w.e. $\mathrm{a}^{-1}$ for 2003-14 estimated in this study agrees with the results of Gardner and others (2013), who determined a mass balance of $-0.49 \pm$ $0.08 \mathrm{~m}$ w.e. $\mathrm{a}^{-1}$ for the entire Tien Shan for 2003-09 using Ice, Cloud and land Elevation Satellite (ICESat) data. For the Akshiirak range, Pieczonka and Bolch (2015) calculated a mass budget of $-0.51 \pm 0.36 \mathrm{mw}^{-e} . \mathrm{a}^{-1}$ during 1975-99, indicating more mass loss than in other regions of the central Tien Shan. The same authors quantified the geodetic mass balance for Glacier No. 354 (Bordu-Juschnaja in their study) from 1975 to 1999 as $-0.79 \pm 0.25$ m w.e. $\mathrm{a}^{-1}$. Since 2003, our assessment indicates a significantly less negative mass balance for Glacier No. 354 relative to the late 20th century. Comparing our results with different studies (Aizen and others, 2006; Dyurgerov, 2010; Gardner and others, 2013; Pieczonka and Bolch, 2015) we confirm the significant mass loss of the investigated glacier over recent decades. We suggest that the mass loss over the past 40 years has continued, but at a somewhat decreased rate during the last decade.

Information on annual mass balance is available for other glaciers in the region. We compare the results from Glacier

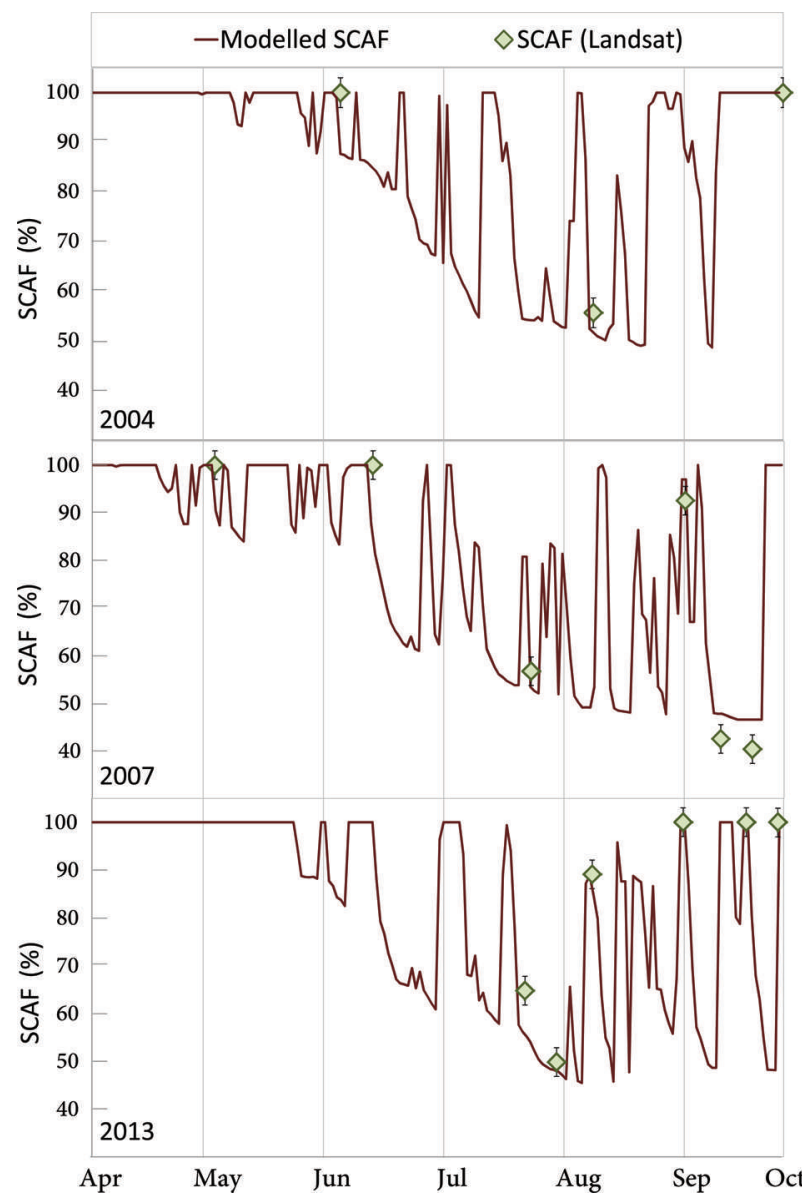

Fig. 6. Validation of modelled snow-covered area fraction with the snow-covered area fraction (SCAF) detected on Landsat imagery for 2004, 2007 and 2013, with estimated uncertainties due to delineation errors of snowline on Landsat images.

No. 354 with those from four other glaciers with direct massbalance measurements. Figure 7 shows the measured annual mass balance of Tuyuksu and Ürümqi No. 1 (e.g. WGMS, 2014), reconstructed values for Gregoriev (e.g. Fujita and others, 2011) located in the Tien Shan, and Abramov in the Pamir-Alay (M. Barandun, unpublished information). For all glaciers, annual mass balances were negative, with the exception of the hydrological year 2008/09, in which a positive or almost balanced mass budget was found. The cumulative mass balances from 2003-12 were -3.59 m w.e. for Glacier No. $354,-5.54 \mathrm{mw}$.e. for Abramov, $-4.62 \mathrm{~m}$ w.e. for Tuyuksu, $-7.26 \mathrm{~m}$ w.e. and $-5.14 \mathrm{~m}$ w.e. for Ürümqi No. 1 east and west, respectively. Reconstructed values for Gregoriev ice cap until 2007 show the most negative annual mass balances for the years 2004-07. Fujita and others (2011) explain mass losses after the 1990s mainly by high air temperatures. For the study period 2003-12, Glacier No. 354 showed the least negative mass balance of the considered glaciers, whereas Ürümqi No. 1 had the most negative mass balance. Ürümqi No. 1 is situated in a relatively dry environment, was split into two branches in 1993 and its mass balance was especially negative after 1996 (Wang and others, 2014a; Zhang and others, 2014). Previous studies mention several reasons for the increased mass loss at Ürümqi No. 1. Wang and others (2014b) discuss an increase in freezing level height and other authors mention a decrease of surface albedo by reduced fresh snowfalls during summer 


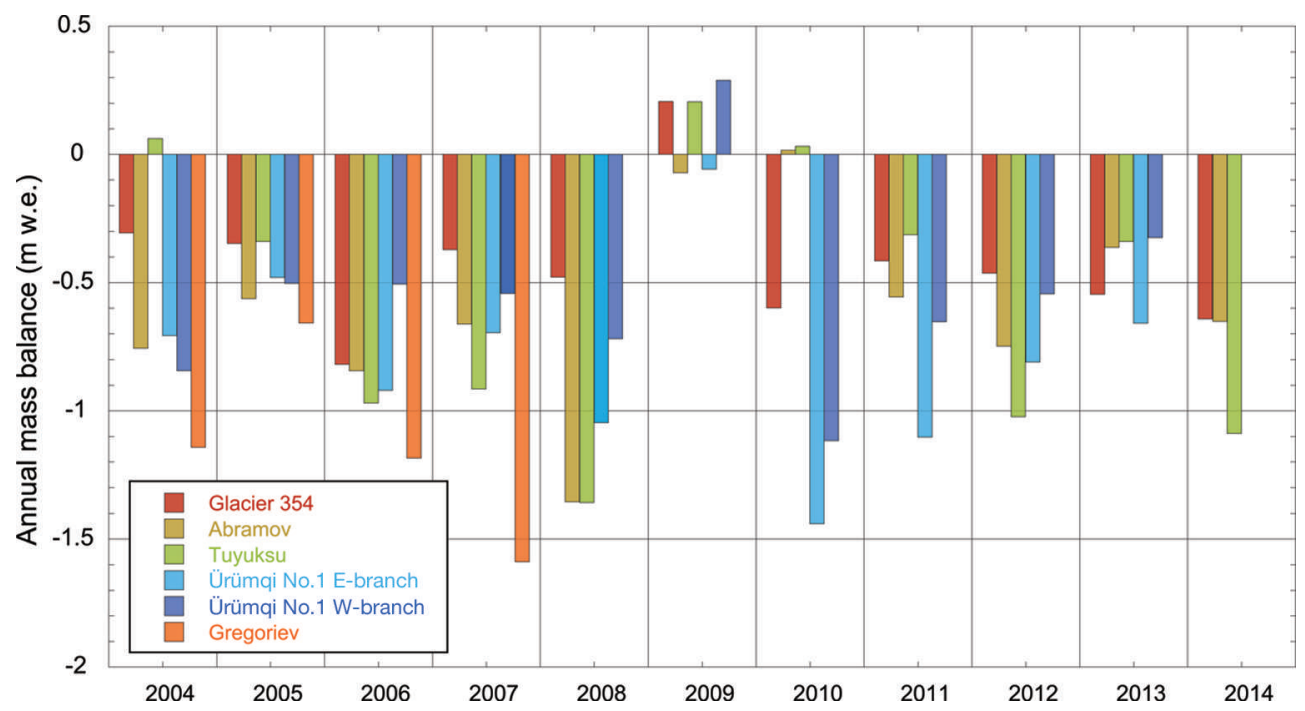

Fig. 7. Comparison of different mass-balance values from reconstructed (Gregoriev), reconstructed and measured (Glacier No. 354 and Abramov) and measured (Tuyuksu and Ürümqi Glacier No. 1) series for six glaciers in central Asia. Values refer to the observation period 2003/04-2011/12. Mass-balance data sources: WGMS (2014) for measured data, Fujita and others (2011) for Gregoriev, and M. Barandun (unpublished information) for Abramov glacier.

and by accumulation of dirty surface materials through increased surface ablation (Fujita and Ageta, 2000; Fujita, 2008a,b; Li and others, 2011).

\section{Mass-balance gradient}

The area-altitude distribution of Glacier No. 354 reveals that the ELA fluctuates around the altitude at which the glacier has its maximum area (Fig. 8). This indicates that the glacier might respond sensitively to a rise in the ELA, as expected with future atmospheric warming. The mean mass-balance gradient in the ablation area is $-0.68 \mathrm{mw}$.e. $(100 \mathrm{~m})^{-1}$, which is similar to values for glaciers in much less continental environments (e.g. Oerlemans, 2001). A minimum gradient of $-0.49 \mathrm{~m}$ w.e. $(100 \mathrm{~m})^{-1}$ was found for 2009 . Past investigations of nearby glaciers indicated lower gradients of $-0.3 \mathrm{~m}$ w.e. $(100 \mathrm{~m})^{-1}$ for Davydov glacier in 1983-95 (Aizen and Zakharov, 1989) and of $-0.4 \mathrm{~m}$ w.e. $(100 \mathrm{~m})^{-1}$ for Sary-Tor in 1985-89 (Ushnurtsev, 1991b). According to Dyurgerov and others (1994) an ongoing change towards higher mass-balance gradients is assumed with a shift in climate conditions.

Such changes in mass-balance gradients are typical for summer-accumulation-type glaciers (Oerlemans, 2001). Glaciers dominated by such mass-balance regimes are characterized by dry winters, and most of the solid precipitation is deposited during summer. Summer accumulation is dominant in the central Tien Shan, and its relative importance increases eastwards, corresponding to the higher continentality (Voloshina, 1988). Summer accumulation strongly influences melt rates via albedo changes, by reducing the absorbed shortwave radiation during the solstice period (Fujita and Ageta, 2000; Fujita, 2008a,b). A small change in summer accumulation has a significant impact on the surface type in the ablation area (snow/ice) and is thus able to change the mass-balance gradient considerably.

Annual accumulation sums (Fig. 4) are substantially higher than the calculated winter balances evaluated on 31 May (Table 4) for all investigated years. The mass-balance evolution over the hydrological year is characterized by an accumulation maximum in summer. The importance of summer accumulation in the region was also noted by Dyurgerov and Mikhalenko (1995), who found substantial differences between the winter balance and annual accumulation as well as between summer balance and annual ablation for Sary-Tor glacier. Thus, the separation of the year into a winter period with no melting and a summer period provides important information on the processes determining the total mass balance.

\section{Internal accumulation and complementary investigations}

In our study, we only considered surface mass balance and did not quantify internal accumulation. For polythermal and

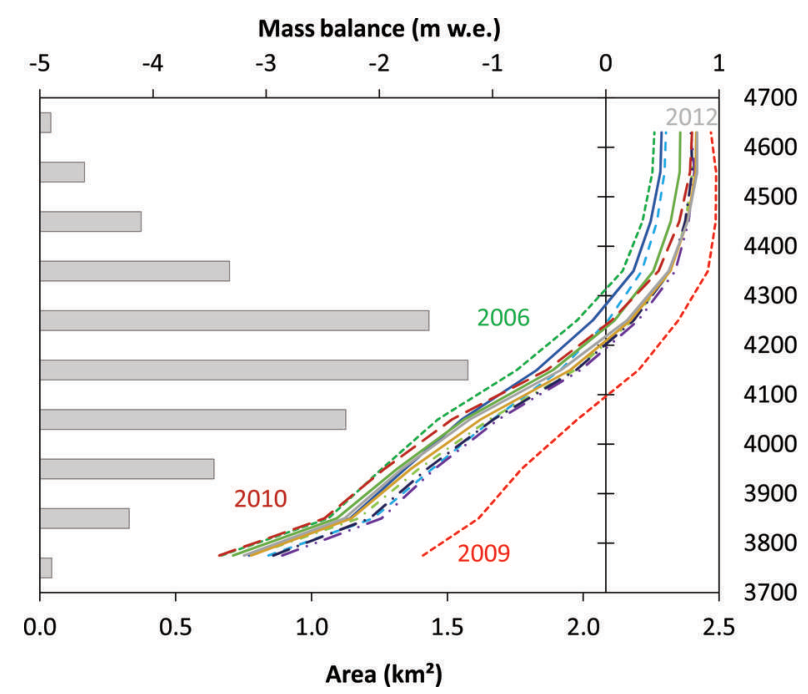

Fig. 8. Elevation dependence of annual mass balance. Dashed curves are for the reconstructed period (2004-10) and solid curves for years with direct observations (2011-14). The lowest (2009), highest (2010) and two nearly average (2006 and 2012) gradients are indicated. Bars show the surface hypsometry in 2012. 
cold glaciers, however, refreezing processes of meltwater beneath the summer surface are not negligible (Cogley and others, 2011) and might have a considerable effect on total mass change. Investigations on Sary-Tor based on repeated snow pits in 1986-89 indicated an average contribution of $22 \%$ internal accumulation to net accumulation (Dyurgerov and Mikhalenko, 1995). Dyurgerov and Mikhalenko (1995) defined internal accumulation as the refreezing of infiltrated water below the previous year's summer surface and considered superimposed ice separately. To assess internal accumulation and superimposed ice at Sary-Tor, Dyurgerov and Mikhalenko (1995) extrapolated data from the location with the maximum thickness of the superimposed ice layer situated close to the ELA over the accumulation area. This assumption was independently controlled with repeated deep snow and firn pits located at $4550 \mathrm{~m}$ a.s.l. The inferred range of uncertainty was $\pm 10 \%$. The mean contribution of superimposed ice to net accumulation at Sary-Tor glacier in 1986-89 was $12 \%$. The highest contribution was observed in years with a positive balance. For the period 1986-89 the mean contribution to the glacier-wide mass balance of SaryTor was $\sim 70 \mathrm{~mm}$ w.e. $\mathrm{a}^{-1}$ by internal accumulation and $\sim 45 \mathrm{~mm}$ w.e. $\mathrm{a}^{-1}$ by superimposed ice, whereas the measured contribution of internal accumulation to Gregoriev ice cap was 180-200 mmw.e. $\mathrm{a}^{-1}$ in 1987 (Dyurgerov and Mikhalenko, 1995). We note that $70 \mathrm{~mm}$ w.e. of internal accumulation for the whole glacier means that $\sim 7.5 \%$ of the meltwater is refrozen below the annual layer $(12 \%$ refreezing of meltwater if superimposed ice is included). This is significantly lower than in colder environments, such as the Tanggula Mountains where refreezing of $20 \%$ of infiltrated water has been reported for Xiao Dongkemadi glacier (Fujita and Ageta, 2000). This variability might be explained by differences in ice temperatures which are about -6 to $-7^{\circ} \mathrm{C}$ at Xiao Dongkemadi glacier (Fujita and others, 1996) and -2.6 to $-3.94^{\circ} \mathrm{C}$ at Gregoriev glacier (Takeuchi and others, 2014) located $<50 \mathrm{~km}$ from Sary-Tor at a similar elevation.

Assuming that the rates of internal accumulation assessed for Sary-Tor are valid for Glacier No. 354 over the last decade, we calculate a contribution of internal accumulation to glacier-wide annual mass balance of about $+0.04 \mathrm{~m}$ w.e. $\mathrm{a}^{-1}$. The uncertainties in these estimates are, however, high, and an exact field determination of internal accumulation rates is difficult. Furthermore, it is likely that internal accumulation showed some changes over time, related to a depletion of the firn volume and a change in firn temperature. We therefore did not explicitly include i nternal accumulation in the mass-balance results evaluated in this study.

The results presented here are based on limited in situ data. Only four years of annual mass-balance measurements were available, and information on snow distribution is based on only one field campaign. More and denser in situ measurements would be beneficial and uncertainties in the results could be reduced if such data were available. However, access to the accumulation area is difficult or impossible, due to crevasses and the risk of avalanches. To complement the measurements, different investigation strategies, such as helicopter-borne radar measurements (e.g. Machguth and others, 2006; Sold and others, 2013), should also be considered. Such investigations might help to improve knowledge of the accumulation pattern rather than repeated in situ snow probings.

\section{CONCLUSIONS}

In this study the seasonal mass balance of Glacier No. 354 was reconstructed for the period 2003-14, based on a combination of glaciological modelling and various in situ and remotely acquired data. By calibrating a spatially distributed mass-balance model driven by daily meteorological data to direct point measurements of ablation and accumulation, the glacier-wide seasonal mass balance for the period 2011-14 was calculated. Using the calibrated model parameter set, mass-balance time series since 2003 were derived. The results show good agreement with (1) independent geodetic ice volume changes derived for the period 2003-12 from two DEMs and (2) observations of the snow-covered area fraction throughout the melting season based on Landsat imagery. We find a modelled cumulative mass balance of $-4.78 \pm 0.98 \mathrm{~m}$ w.e. for the period 2003-14, with a mean annual value of $-0.43 \pm$ 0.09 m w.e. $\mathrm{a}^{-1}$. A similar mass loss was found, independent of any meteorological information, by the geodetic method. By combining in situ glaciological observations and geodetic surveys with modelling it is possible to downscale the decadal mass loss to sub-seasonal changes. Thanks to this increased temporal resolution, the massbalance evolution and the underlying processes can be addressed.

The last decade is characterized by a scarcity of direct information on glacier mass balance in the Tien Shan. Limited availability of long-term series of seasonal mass balance hampers understanding of the drivers of regional glacier change. We show that the glacier mass balance was persistently negative throughout the last decade, with only one year with a balanced mass budget. This supports the results of several remote-sensing studies and thus indicates a strong imbalance of glaciers in the central Tien Shan. The reestablishment of glacier mass-balance observations based on a combination of in situ and remote methods is crucial for improved process-based estimates of glacier response to climate change in this region, and as a basis for future runoff studies. The mass-balance series presented in this study is expected to be a new starting point for long-term massbalance observations in one of the most glacierized regions in central Asia, contributing data to the Global Terrestrial Network for Glaciers (GTN-G) within the Global Climate Observing System (GCOS).

\section{ACKNOWLEDGEMENTS}

This project was made possible by the support of the Federal Office of Meteorology and Climatology MeteoSwiss through the project Capacity Building and Twinning for Climate Observing Systems (CATCOS), contract no. 7F-08114.1, between the Swiss Agency for Development and Cooperation (SDC) and MeteoSwiss. This study is supported by the Swiss National Science Foundation (SNSF), grant 200021_155903, and a young scientist grant from the Swiss Society for Hydrology and Limnology (SGHL/SSHL). Additional support from the German Federal Foreign Office in the frame of the CAWa project (contract No. AA7090002, http://www.cawa-project.net), the European Space Agency project Glaciers_cci (4000109873/14/I-NB) and the European Research Council (FP/2007-2013, ERC grant agreement No. 320816) are equally acknowledged. We are also grateful to the Central Asian Institute for Applied Geosciences for their collaboration, especially to B. Moldobekov 
for his continuous support. The Kumtor Gold Company provided the meteorological data. We thank N. Salzmann, H. Machguth, J. Schmale and everybody else who contributed to the fieldwork. We thank K. Fujita for sharing the data for Gregoriev ice cap and his constructive comments as scientific editor of this paper. We also thank S. Kutuzov and an anonymous reviewer for helpful comments.

\section{REFERENCES}

Aizen VB and Aizen EM (1997) Hydrological cycles on the north and south peripheries of mountain-glacial basins of Central Asia. Hydrol. Process., 11, 451-469 (doi: 10.1002/(SICI)1099-1085 (199704)11:5<451::AID-HYP448>3.0.CO;2-M)

Aizen VB and Zakharov VG (1989) Mass balance and ice flow velocity of Davydov Glacier basing on research in 1984-1985. Data Glaciol. Stud., 67, 197-202 [in Russian]

Aizen VB, Aizen EM and Melack JM (1995) Climate, snow cover, glaciers, and runoff in the Tien Shan, Central Asia. Water Resour. Bull., 31(6), 1113-1129 (doi: 10.1111/j.1752-1688.1995. tb03426.x)

Aizen VB, Kuzmichenok VA, Surazakov AB and Aizen EM (2006) Glacier changes in central and northern Tien Shan during the last 140 years based on surface and remote-sensing data. Ann. Glaciol., 43, 202-213 (doi: 10.3189/172756406781812465)

Allouche J (2007) The governance of Central Asian waters: national interests versus regional cooperation. Disarmament Forum 2007, 4, 45-56

Bolch T (2007) Climate change and glacier retreat in Northern Tien Shan (Kazakhstan/Kyrgyzstan) using remote sensing data. Global Planet. Change, 56, 1-12 (doi: 10.1016/j.gloplacha.2006. 07.009)

Bolch T (2015) Glacier area and mass changes since 1964 in the Ala Archa Valley, Kyrgyz Ala-Too, northern Tien Shan. Ice and Snow, 129(1), 28-39

Braithwaite RJ and Olesen OB (1989) Calculation of glacier ablation from air temperature, West Greenland. In Oerlemans J ed. Glacier fluctuations and climatic change. Kluwer Academic Publishers, Dordrecht, 219-233

Cogley JG and 10 others (2011) Glossary of glacier mass balance and related terms. (IHP-VII Technical Documents in Hydrology No .86, IACS Contribution No. 2) UNESCO-International Hydrological Programme, Paris

Dyurgerov MB (2010) Reanalysis of glacier changes: from the IGY to the IPY, 1960-2008. Data Glaciol. Stud., 108, 1-116

Dyurgerov MB and Mikhalenko VN eds (1995) Oledeneniye Tien Shanya [Glaciation of Tien Shan], VINITI, Moscow [in Russian]

Dyurgerov MB, Mikhalenko VN, Kunakhovitch MG, Ushnurtsev SN, Liu C and Xie Z (1994) On the cause of glacier mass balance variations in the Tien Shan mountains. Geo/ournal, 33(2-3), 311-317 (doi: 10.1007/BF00812879)

Economic Commission for Europe (ECE) (2011) Second assessment of transboundary rivers, lakes and groundwaters. Convention on the Protection and Use of Transboundary Watercourses and International Lakes. United Nations, New York and Geneva

Elsberg DH, Harrison WD, Echelmeyer KA and Krimmel RM (2001) Quantifying the effects of climate and surface change on glacier mass balance. J. Glaciol., 47(159), 649-658

Farinotti D, Magnusson J, Huss M and Bauder A (2010) Snow accumulation distribution inferred from time-lapse photography and simple modelling. Hydrol. Process., 25(14), 2087-2097 (doi: 10.1002/hyp.7629)

Fujita K (2008a) Influence of precipitation seasonality on glacier mass balance and its sensitivity to climate change. Ann. Glaciol., 48, 88-92 (doi: 10.3189/172756408784700824)

Fujita K (2008b) Effect of precipitation seasonality on climatic sensitivity of glacier mass balance. Earth Planet. Sci. Lett., 276(1-2), 14-19 (doi: 10.1016/j.epsl.2008.08.028)
Fujita K and Ageta Y (2000) Effect of summer accumulation on glacier mass balance on the Tibetan Plateau revealed by massbalance model. J. Glaciol., 46(153), 244-252 (doi: 10.3189/ 172756500781832945)

Fujita K, Seko K, Ageta Y, Pu JC and Yao TD (1996) Superimposed ice in glacier mass balance on the Tibetan Plateau. J. Glaciol., 42(142), 454-460

Fujita K and 6 others (2011) Favorable climatic regime for maintaining the present-day geometry of the Gregoriev Glacier, Inner Tien Shan. Cryosphere, 5(3), 539-549 (doi: 10.5194/tc-5539-2011)

Gardelle J, Berthier E, Arnaud Y and Kääb A (2013) Region-wide glacier mass balances over the Pamir-Karakoram-Himalaya during 1999-2011. Cryosphere, 7(4), 1263-1286 (doi: 10.5194/ tc-7-1263-2013)

Gardner AS and 15 others (2013) A reconciled estimate of glacier contributions to sea level rise: 2003 to 2009. Science, 340(6134), 852-857 (doi: 10.1126/science.1234532)

Haeberli W, Hoelzle M, Paul F and Zemp M (2007) Integrated monitoring of mountain glaciers as key indicators of global climate change: the European Alps. Ann. Glaciol., 46, 150-160

Hagg W, Braun L, Uvarov V and Makarevich K (2004) A comparison of three methods of mass-balance determination in the Tuyuksu glacier region, Tien Shan, Central Asia. J. Glaciol., 50(171), 505-510 (doi: 10.3189/172756504781829783)

Hagg W, Mayer C, Lambrecht A, Kriegel D and Azizov E (2013) Glacier changes in the Big Naryn basin, Central Tian Shan. Global Planet. Change, 110(A), 40-50 (doi: 10.1016/j.gloplacha. 2012.07.010)

Hock R (1999) A distributed temperature-index ice- and snowmelt model including potential direct solar radiation. J. Glaciol., 45(149), 101-111

Hock R (2003) Temperature index melt modelling in mountain areas. J. Hydrol., 282, 104-115 (doi: 10.1016/S0022-1694(03) 00257-9)

Höhle J and Höhle M (2009) Accuracy assessment of digital elevation models by means of robust statistical methods. ISPRS J. Photogramm. Rem. Sens., 64(4), 398-406 (doi: 10.1016/ j.isprsjprs.2009.02.003)

Hulth J, Rolstad Denby C and Hock R (2013) Estimating glacier snow accumulation from backward calculation of melt and snowline tracking. Ann. Glaciol., 54(62), 1-7 (doi: 10.3189/ 2012AoG3162A3083)

Huss M (2013) Density assumptions for converting geodetic glacier volume change to mass change. Cryosphere, 7(3), 877-887 (doi: 10.5194/tc-7-877-2013)

Huss M, Bauder A, Funk M and Hock R (2008) Determination of the seasonal mass balance of four Alpine glaciers since 1865 . J. Geophys. Res., 113(F1), F01015, 2156-2202 (doi: 10.1029/ 2007JF000803)

Huss M, Bauder A and Funk M (2009). Homogenization of longterm mass-balance time series. Ann. Glaciol., 50, 198-206 (doi: $10.3189 / 172756409787769627)$

Huss $M$ and 6 others (2013) Towards remote monitoring of subseasonal glacier mass balance. Ann. Glaciol., 54(63), 85-93 (doi: 10.3189/2013AoG63A427)

Kaser G, Grosshauser M and Marzeion B (2010) Contribution potential of glaciers to water availability in different climate regimes. Proc. Natl Acad. Sci. USA (PNAS), 107(47), $20223-$ 20227 (doi: 10.1073/pnas.1008162107)

Khromova TE, Dyurgerov MB and Barry RG (2003) Latetwentieth century changes in glacier extent in the Ak-shirak Range, Central Asia, determined from historical data and ASTER imagery. Geophys. Res. Lett., 30(16), 1863 (doi: 10.1029/2003GL017233)

Khromova T, Nosenko G, Kutuzov S, Muraviev A and Chernova L (2014) Glacier area changes in Northern Eurasia. Environ. Res. Lett., 9, 015003 (doi: 10.1088/1748-9326/9/1/015003)

Kriegel D and 6 others (2013) Changes in glacierisation, climate and runoff in the second half of the 20th century in the Naryn 
basin, Central Asia. Global Planet. Change, 110(A), 51-61 (doi: 10.1016/j.gloplacha.2013.05.014)

Li ZQ, Li HL and Chen YN (2011) Mechanisms and simulation of accelerated shrinkage of continental glaciers: a case study of Urumqi Glacier No. 1 in Eastern Tianshan, Central Asia. J. Earth Sci., 22(4), 423-430 (doi: 10.1007/s12583-011-0194-5)

Machguth H, Eisen O, Paul F and Hoelzle M (2006) Strong spatial variability of snow accumulation observed with helicopterborne GPR on two adjacent Alpine glaciers. Geophys. Res. Lett., 33(13), L13503 (doi: 10.1029/2006GL026576)

Narama C, Kääb A, Duishonakunov M and Abdrakhmatov K (2010) Spatial variability of recent glacier area changes in the Tien Shan Mountains, Central Asia, using Corona ( 1970), Landsat $(\sim 2000)$ and ALOS $(\sim 2007)$ satellite data Global Planet. Change, 71(1-2), 42-54 (doi: 10.1016/j.gloplacha.2009.08.002)

Nuth C and Kääb A (2011) Co-registration and bias corrections of satellite elevation data sets for quantifying glacier thickness change. Cryosphere, 5, 271-290 (doi: 10.5194/tc-5-271-2011)

Oerlemans J (1994) Quantifying global warming from the retreat of glaciers. Science, 264(5156), 243-245 (doi: 10.1126/ science.264.5156.243)

Oerlemans J (2001) Glaciers and climate change. AA Balkema Publishers, Lisse

Ohmura A (2001) Physical basis for the temperature/melt-index method. J. Appl. Meteorol., 40, 753-761

Ozmonov A, Bolch T, Xi C, Wei J and Kurban A (2013) Glacier characteristics and changes in the Sary-Jaz River Basin (Central Tien Shan) 1990-2010. Remote Sens. Lett., 4(8), 725-734 (doi: 10.1080/2150704X.2013.789146)

Paul F and 17 others (2013) On the accuracy of glacier outlines derived from remote-sensing data. Ann. Glaciol., 54(63), 171-182 (doi: 10.3189/2013AoG63A296)

Pellicciotti FB, Brock W, Strasser U, Burlando P, Funk M and Corripio J (2005) An enhanced temperature-index glacier melt model including the shortwave radiation balance: development and testing for Haut Glacier d'Arolla, Switzerland. J. Glaciol., 51(175), 573-587

Pelto M (2011) Utility of late summer transient snowline migration rate on Taku Glacier, Alaska. Cryosphere, 5(4), 1127-1133 (doi: 10.5194/tc-5-1127-2011)

Petrakov DA, Lavrientiev II, Kovalenko NA and Usubaliev RA (2014) Ice thickness, volume and modern change of the SaryTor Glacier Area (Ak-Shyirak Massif, Inner Tian Shan). Kriosfera Zemli, 18(3), 91-100 [in Russian]

Pieczonka T and Bolch T (2015) Region-wide glacier mass budgets and area changes for the Central Tien Shan between $\sim 1975$ and 1999 using Hexagon KH-9 imagery. Global Planet. Change, 128, 1-13 (doi: 10.1016/j.gloplacha.2014.11.014)

Pieczonka T, Bolch T, Wei J and Liu S (2013) Heterogeneous mass loss of glaciers in the Aksu-Tarim catchment (Central Tien Shan) revealed by $1976 \mathrm{KH}-9$ Hexagon and 2009 SPOT-5 stereo imagery. Remote Sens. Environ., 130, 233-244 (doi: 10.1016/j. rse.2012.11.020)

Sold L, Huss M, Hoelzle M, Andereggen H, Joerg P and Zemp M (2013) Methodological approaches to infer end-of-winter snow distribution on alpine glaciers J. Glaciol., 59(218), 1047-1059 (doi: 10.3189/2013JoG13J015)

Sorg A, Bolch T, Stoffel M, Solomina O and Beniston M (2012) Climate change impacts on glaciers and runoff in Central Asia. Nature Climate Change, 2, 725-731 (doi: 10.1038/ nclimate1592)

Sorg A, Huss M, Rohrer M and Stoffel M (2014) The days of plenty might soon be over in glacierized Central Asian catchments. Environ. Res. Lett., 9(10), 104018 (doi: 10.1088/1748-9326/9/ 10/104018)

Takeuchi N and 7 others (2014) The disappearance of glaciers in the Tien Shan Mountains in Central Asia at the end of Pleistocene. Quat. Sci. Rev., 103, 26-33 (doi: 10.1016/j.quascirev. 2014.09.006)

Thibert E, Blanc R, Vincent C and Eckert N (2008) Instruments and methods. Glaciological and volumetric mass-balance measurements: error analysis over 51 years for Glacier de Sarennes, French Alps. J. Glaciol., 54(186), 522-532 (doi: 10.3189/ 002214308785837093)

Unger-Shayesteh K and 6 others (2013) What do we know about past changes in the water cycle of Central Asian headwaters? A review. Global Planet. Change, 110(A), 4-25 (doi: 10.1016/j. gloplacha.2013.02.004)

Ushnurtsev SN (1991a) Mass balance fluctuations of the Sary-Tor glacier in inner Tien Shan and its reconstruction for the period 1930-1988. Data Glaciol. Stud., 71, 70-79 [in Russian]

Ushnurtsev SN (1991b) Experimental studies of glacier regime in Inner Tien Shan for calculations and monitoring of mass balance and runoff. (PhD thesis, Institute of Geography, Russian Academy of Sciences, Moscow) [in Russian]

Voloshina AP (1988) Climate and meteorological features of glacier covered area in the Akshiirak massif. Data Glaciol. Stud., 62, 184-193 [in Russian]

Wang P, Li Z, Li H, Wang W and Yao H (2014a) Comparison of glaciological and geodetic mass balance at Glacier No. 1, Tian Shan, Central Asia. Clobal Planet. Change, 114, 14-22 (doi: 10.1016/j.gloplacha.2014.01.001)

Wang S and 6 others (2014b) Recent changes in freezing level heights in High Asia and their impact on glacier changes. J. Geophys. Res.: Atmospheres, 119, 1-13 (doi: 10.1002/ 2013JD020490)

Wu Y, He J, Guo Z and Chen A (2014) Limitations in identifying the equilibrium-line altitude from the optical remote-sensing derived snowline in the Tien Shan, China. J. Glaciol., 60(224), 1093-1099 (doi: 10.3189/2014JoG13J221)

World Glacier Monitoring Service (WGMS) (2012) Fluctuations of glaciers 2005-2010 (Vol. IX) ed. Zemp M and 6 others. ICSU (WDS)/IUGG(IACS)/UNEP/UNESCO/WMO, World Glacier Monitoring Service, Zürich

WGMS (2014) Fluctuations of glaciers database. World Glacier Monitoring Service, Zürich (doi: 10.5904/wgms-fog-2014-09) http://dx.doi.org/10.5904/wgms-fog-2014-09

Zhang G, Li Z, Wang W and Wang W (2014) Rapid decrease of observed mass balance in the Urumqi Glacier No. 1, Tianshan Mountains, central Asia. Quat. Int., 349, 135-141 (doi: 10.1016/j.quaint.2013.08.035) 